\title{
Normative Model Of New-Woman: A Discourse Of Ten Female Protagonists Of Urdu TV Drama Serials (2010-2019)
}

\author{
Saleem Abbas \\ \& \\ Firasat Jabeen \\ Department of Mass Communication \\ Forman Christian College University \\ Muhammad Askari \\ Department of Mass Communication \\ University of Karachi
}

\begin{abstract}
This paper examines the normative model of 'new woman' (Dutoya 2018) in Pakistani dramas from the perspective of gender, class, and culture. TV drama is a predominant form of entertainment in Pakistani media. In early Urdu dramas, female characters are infrequently depicted in a progressive way but now, educated, independent, and urban middle-class women can generally be observed in lead and supporting roles. Along with a shift of female representation in Pakistani Urdu dramas, the study discusses the construction of a Pakistani normative model of 'new womanhood.' Through a qualitative content analysis of ten female protagonists from Pakistani Urdu TV dramas of last decade (2010 through 2019), I argue that Dutoya's socially permissible model of 'new woman' can be noticed in the majority of contemporary Urdu dramas. In other words, female protagonists are portrayed with diverse attributes of modesty and modernity. I further argue that the idea of 'new woman' is not a new phenomenon for the Pakistani society. Unlike a colonial idea of 'super wife' and Victorian concept of 'super woman,' my assertion is that Pakistani version of 'new woman' is a response to western wave of feminism, religious orthodoxy at home, and cultural conservatism prevalent in Pakistan.
\end{abstract}

Keywords: Women Portrayal, Pakistani Urdu Drama, New-Womanhood, Television Drama, Gender Representation, Stereotypes.

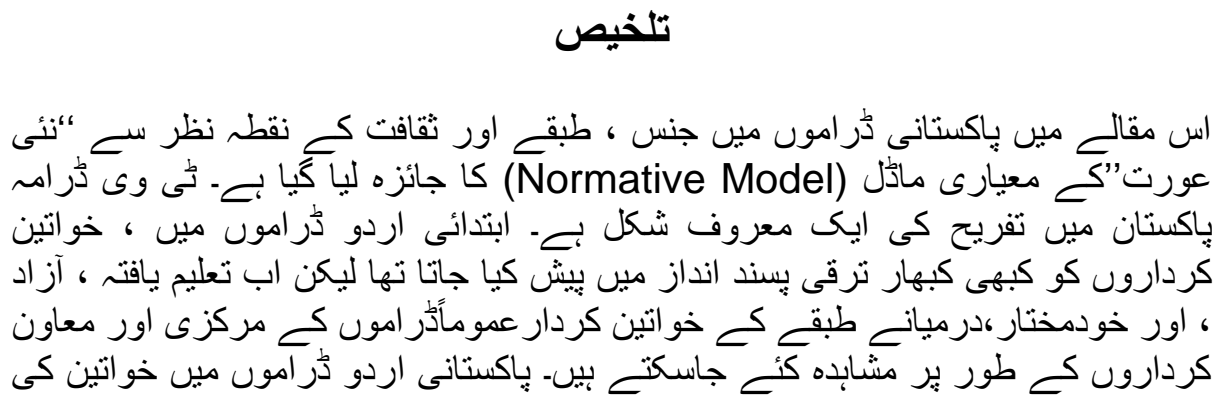

This work is Licensed under a Creative Commons Attribution-NonCommercial 4.0 International License (c) (7) (8) 


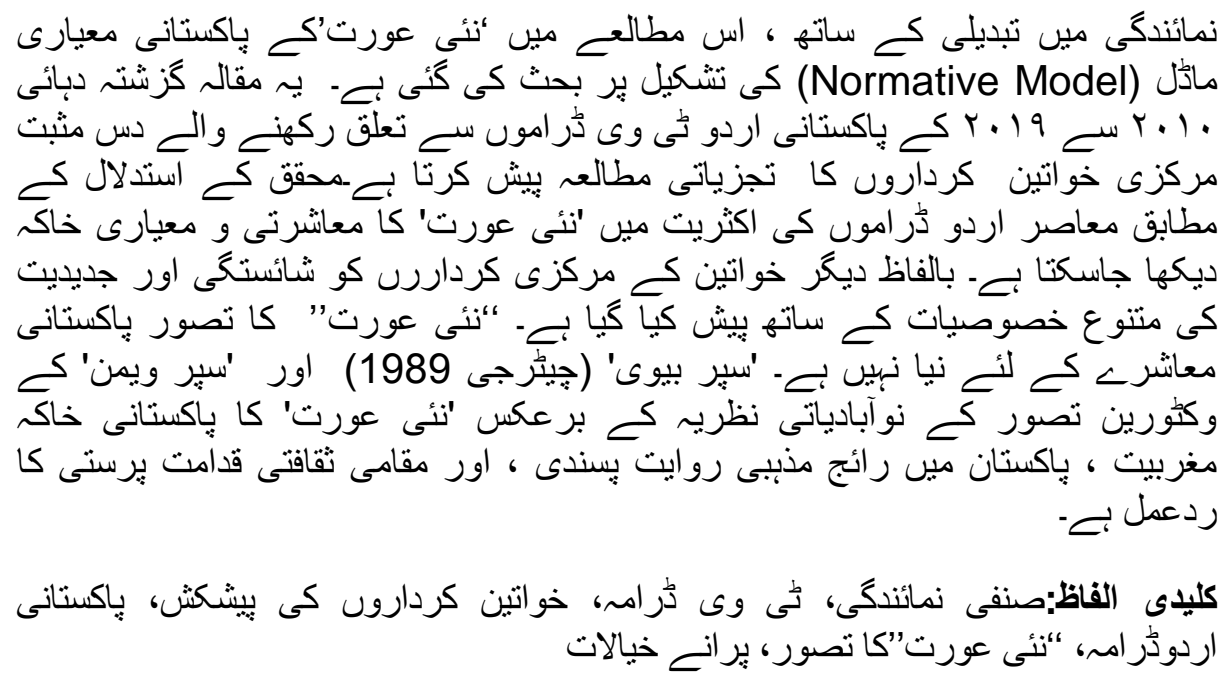

\section{Introduction}

In response to Islamized capitalist patriarchy, social oppression, and class inequalities in Pakistan(H. A. Shah, 2018), a self-constructed identity of new-womanhood can be observed in the society(Hussein, 2018b). The Contemporary Pakistani media generally depict the same normative model of 'new-woman' through its television drama serials (Dutoya, 2018a). The model showcases urban middle-class, educated and independent women who have higher professional achievements and capability in household skills. The model is an embodiment of contrasting qualities. On one hand new-woman is progressive and eager to achieve education and self-reliance, on the other hand she bears the abilities of being cooperative and conventional. Her motivation towards selfempowerment raises her status from an uneducated lower-class woman, and her respectful attitude towards eastern values puts her in a juxtaposition of non-traditional westernized female of upper-class.

In this paper, I discuss the idea of 'new woman' - a modified form of Victorian style 'super woman'(Hussein, 2018b), or colonial 'super wife'(Walsh and Chatterjee 2001; Dutoya 2018b) or Urdu novelist, Nazeer Ahmad's character of courteous daughter-in-law, Asghari (Deputy Nazeer Ahmed, n.d.) - in the perspective of Pakistani Urdu TV dramas. Since 1970s Pakistani dramas have occasionally presented these female characters as protagonists. The heroines of Pakistani playwright Hassina Moeen's dramas - Kiran Kahani (1973), Tanhaiyaan (1985) and Dhoopkenare (1987) are perfect cases in point to demonstrate the idea of new womanhood.

In the post-Islamization period (1988 to date),especially during the last two decades, the normative model of 'new woman' can be seen more frequently in the Urdu TV dramas as 
a continuity of progressive, energetic, independent, and loving heroines of Hassina Moin. This model is accommodating and traditional but educated and sensible at the same time. She works hard to maintain her identity and a balance among modernity, tradition, and religion. This study explores the rebirth of 'new woman' and discusses the wave of Pakistani brand of new womanhood in contemporary television shows.

Pakistani dramas are one of the predominant and popular source of entertainment among Urdu speaking diaspora ("Hiten Tejwani Keen to Work in a Pakistani TV Drama," 2014; "Saudi Arabia Interested to Show Pakistani TV Dramas on Saudi Channels," 2018).With the inception of Pakistan Television (PTV) in 1964, Urdu TV dramas have been the most selling product among all television shows (Hasan, 2000). The popularity graph of these dramas fluctuates with the passage of time but the tradition of storytelling does not lose its attraction. Pakistani dramas generally depict the ideology of the people who are associated with the institution of television and drama industry. Mainly the heterogeneous representation of gendered characters is directly associated with ideology and values of the society. As Dawkins and Wynd (2009) discussed that media texts such as movies and other scripted visuals are always constructed artifacts. Similarly, Pakistani scripted television shows also offer constructed realities. Persons who are associated with drama industry, take certain choices about the content and style. Their believes, power, and skills play a role in the formation of a narrative (Dawkins and Wynd 2009. pp.14). More often than not these choices reflect their personal biases and influences. In the early days of Pakistan Television, one of the key objectives of this medium was to promote local culture and art (Hasan, 2000), but eventually the state owned TV channel (Pakistan Television (PTV) was used to serve the purpose of different political regimes (Anand, 2014).

In 1970s, political environment of Pakistan was progressive and liberal (S. M. H. Shah \& Panhwar, 2014), so the TV shows before 1977, reflect both traditional and liberal culture. It was the beginning of a new but powerful visual medium in Pakistan. At that time, Hassina Moin combined modernity with tradition and constructed a commonly acceptable model of woman on Pakistani Television screen. Moin introduced a middleclass, educated, and nontraditional female protagonists in her early dramas of 1970s and 1980s (Parvez, 1998). She wrote many dramas and the majority of them went super hit. Kiran Kahani (1973), Tanhaiyaan (1985), and DhoopKinare (1987) are among those popular dramas in which optimistic girls of educated urban middle-class are portrayed in lead roles.

In the period of Islamization (1977-88), the narrative of Pakistani television dramas is ultratraditional. They depict dichotomy of good and bad women through ideological codes. Religiously conservative, submissive, and docile females are presented as a role model in Pakistani society (Kothari, 2005). A respectful and obedient attitude towards male head of 
the family is generally reinforced and an unquestionable authority of husbands is upheld (Mumtaz \& Shaheed, 1987) through these dramas. The female characters are portrayed in proper Islamic attire (i.e., with full body suits and head coverings). Women, who act outside the joint family system and reject caring and nurturing roles, (Hussein, 2018a)not following the persistent religion-traditional norms were considered rebellious, disobedient of elders, westernized and deviant women (Abbas, 2018).

\section{Review of Literature}

From 1964 to date, Pakistani television shows have been presenting a variety of Pakistani female images. These images vary according to the policies of the state governments. From an oppressed illiterate and helpless rural female to an ultramodern westernized urban woman, there is a whole spectrum of different female roles that reflect different shades of Pakistani womanhood. These mixed female images contain different media messages that constantly question their identity and role in local and global culture (Carilli \& Campbell, 2013). Past studies of women portrayal in Pakistani media, generally reflect gender inequality and discrimination. Most of these studies focus on the martial-law regime of Zia-ul-Haq (1977-1988) and its aftermaths(Cheema, 2018; Iqbal, 2012; Pal, 1990; Weiss, 1990). During this time period-known as Islamizationregulations concerning language, women's dress, mass media, and education based on Islamic principles are introduced. Thus, female experiences are policed and controlled by the state (Silva, 2003).

The majority sociopolitical trajectories of the country are formalized into religion during the period of 'Islamization'. Another dominating patriarchal slogan of that time is 'veil and four-walls' that deduces women as 'femme fatale', who if go outside the domestic limits will bring shame and disrespect for male members of the family (Mumtaz \& Shaheed, 1987). Most of Pakistani Urdu dramas of 1980s depict good woman with domestic, religious and submissive female characters. The connections of these attributes can be seen in sharif and good Muslim woman's model of Maulana Ashraf Ali Thanvi, a Deobandi scholar. Thanvi (2000) published a monumental female curriculum, the Bahishtizewar in 1905 (Thanvi, 2000). In the late colonial era, Ashraf Ali Thanvi wrote this book as an Islamic reformer for the Muslim women of India. He actively participated in the Islamic reformers' movement of colonial era of nineteenth century. The majority of reformers in this movement were male, religious, and literary scholars including Thanvi himself, Sir Syed Ahmad Khan, Nazir Ahmad, Altaf Hussain Hali, Mumtaz Ali, and Shaykh Abdullah (Devji, 1991). Thanvi's description about shurafa (elite) Muslim women is publicized through media as a role model for Pakistani Muslim women during the Zia regime in 1980s. Throughout the regime until 1990s, presenting a copy of this book as a wedding gift to girls was a common practice in many traditional Muslim 
families. Additionally, common domestic roles of mothers, sisters, daughters and housewives in Pakistani TV dramas are encoded from the perspective of the same book. Under the influence of the movement related to the reforms of women conditions in India, Nazir Ahmad published his first novel titled the Mirat-al-Uroos in 1869. The movement focused on female education - the basics of which were literacy, home economics, and 'orthodox' practices (Devji, 1991). In the novel, Nazir Ahmad emphasized women education and the moral training of young girls. The novel is televised multiple times in 1989, 2011, 2012 on Pakistan Television, HUM TV, and Geo TV channels respectively. His female protagonists are traditional and flag-bearer of moral values. They are educated but their education helps them become better homemaker (Moolji, 2018). Chatterjee describes the similar attributes in a colonial good Indian wife who devotes her life to her home and family (Kopf, 1995).

The occasional presentation of professional and independent female characters in Urdu dramas are often criticized by traditionalists. That is why early Pakistani Urdu dramas are produced with a dominating patriarchal approach. The majority male characters in early dramas are depicted in professional, managerial and powerful roles. Traditionalist religious leaders, however, do not want women to work outside the domestic confines and hold any public office, though some conservative writers would permit women to take up part-time jobs in those fields where they are likely to have no direct contact with male strangers (Pal, 1990). This hegemonic patriarchal approach is challenged by feminists and many modernist Muslim scholars. They have always questioned the doctrinal validity of the position of the traditionalist ulama (religious scholars) concerning the implementation of Islamic law in modern times(Pal, 1990). The portrayal of 'good' and 'bad' women in Urdu dramas (Abbas, 2018), explains hegemonic patriarchal agenda. This agenda was labeled with religion to avoid possible criticism and to have vast acceptance in the Pakistani Muslim society. There were severe consequences for those women who flouted traditional Islamic norms of decency (Talib \& Idrees, 2012). The retention of this image in the collective memory of the nation can be observed through the two incidents from different eras that reflect male dominating attitude towards females. Although these reverberations of 'Islamization' are challenged by feminist scholars in current media discourses, the misogynistic mindset and some quaint traditions survive to this day. Silva (2003) quotes an incident of 1996, when Benazir Bhutto- the first female Prime Minister of Pakistan-was in power, Maulana Naqshbandi - one of Pakistan's prominent cleric at that time - asserted that "Any nation that made a woman its ruler has never prospered" (cited in The Pakistan Times, 11 March 1996, 27). He declared this after Pakistan's defeat in a cricket match with India in March 1996. Another incident occurred in April 2020 during a fundraising telethon on national television networks when in a televised prayer, Maulana Tariq Jameel-another wellknown Islamic cleric made a proclamation that COVID-19 has been unleashed on 
humanity because of the 'wrongdoing of women' (Editorial, Dawn 26 April, 2020). These remarks were made in the presence of the country's Prime Minister, Imran Khan and top broadcast journalists. The misogynistic remarks made by both Islamic clerics encode a specific male dominating approach towards the females of Pakistani society.

Besides the presentation of conservative and subservient images of domestic women Pakistani media also presents female images of religious modernity. These images are opposite to an image of western woman and far beyond archetypal images of 'Islamization' era(Jamal, 2013). The active and collective female participation of Jamat-eIslami-a religious political party - in religious and political affairs is the proof of religious modernity. In the current scenario, majority of religious parties and organizations (e.g. Jamat Ahl-e-Sunat, Minhaj-ul-Quran, and Majlis Wahdat-eMuslimeen etc.) have formed their women wings that actively perform religious, social and political activities. These religious organizations do not compromise on women appearances who wear traditional dresses with head coverings and sometimes complete veil and hijab. The persuasion of women's career in limited but professional fields is among the religious organizations' objectives. These female images with professional and academic achievements are way ahead from a subservient and dependent religious pictures of Muslim Indian women of the nineteenth century (Chatterjee 1989) or conservative images of semiliterate, domestic and the Taliban influenced girls of Sawat.

Another aspect of television representational practices is the maximum depiction of middle-class that not only reproduces the patrilineal family but also demarcates the home as the site for moral instruction (tarbiyat) and schools as places where education (talim) linked to waged-work takes place (Moolji, 2018). Television content frequently broadcast imageries of middle class of the society. One main reason of this depiction is that almost all dramatists and production crew belong to the middle-class of the society. Having experience of the same stratum of the society, they comfortably create stories and characters of the same class and discuss the challenges and perception from their point of view. After the proliferation of television channels (in 2002) and commencement of a policy of liberalization, dramas frequently present stories linked with lower to upper middle-class economic status. There is also a change in the thematic presentation of TV dramas. Controversial issues such as honor killings, adultery, stoning to death, domestic violence, marriage after divorce and homosexuality have started appearing on screen (Cheema, 2018). Over time Pakistani dramas have both reiterated and challenged the perception that the home is a domain of power and of confinement at the same time.

Moreover, majority of the Pakistani media channels are owned and administered by male folk. More often than not women who get access to the public spheres, have to act according to the given directions and guidelines. They have to navigate through their intersecting identities as Muslims, women and Pakistanis from their assigned screen roles 
(Cheema, 2018). Most of the time television content especially dramas re-inscribe women's role according to the established cultural norms. Similarly, advertising which is a multi-billion dollar industry, mainly relies upon cultural stereotypes (Kilbourne, 1999). The producers of advertisements and dramas mostly use culturally constructed female body images to acquire wide acceptance of their products(Reimer \& Ahmed, 2012). Most of the time producers' broadcasting choices bring criticism to female assigned appearances. Sometimes these televised commercial messages work as tools of women subjugation (Frith \& Karan, 2008). The diverse portrayal of women stimulate questions about the cultural and philosophical contexts that shape the life experiences of women in Asia (Frith \& Karan, 2008). Challenging images of women in the media scrutinizes issues of race, ethnicity, class, and sexuality through a study of gendered media portrayals (Carilli \& Campbell, 2013).

For the last two decades, visual media particularly Pakistani TV dramas are persistently constructing an image of new Pakistani womanhood. The majority of these dramas depict strong female characters with shared qualities and skills. The images of these central female characters are a combination of eastern and western attributes. Although the new contemporary Pakistani female images of media are distant from western style liberalism, they depict their own way of life that is still based on rationality and enlightenment.

\section{Methodology}

In this paper, I trace and discuss examples from ten contemporary Pakistani Urdu TV dramas serials from 2010-2019. The details of these drams can be seen in Table \# 1. I delve in the study of dramas to find the answers of following research questions:

1) How do Pakistani Urdu TV dramas portray new woman balancing between traditionalism and modernity?

2) What basic talents and competencies are presented in these dramas related to the personality of new-womanhood?

3) What socio-economic status and intersectional oppressions of these female protagonists are showcased in Pakistani dramas?

To answer aforementioned questions, I used qualitative content analysis and studied ten main female roles from ten Pakistani Urdu television serials from 2010-2019. These drama serials include Daam (2010), Hamsafar (2011), Durr-e-Shahwar (2012), Zindagi Gulzar Hai (2013), Digest Writer (2014), Diyar-e-Dil (2015), Gul-e-Rana (2016), Yaqeen Ka Safar (2017), Khaani (2018), and Ehde Wafa (2019). With the help of four research assistants, I examined dialogues as well as frames of these dramas. To ensure the inter coder reliability, I have shared a complete coding sheet during training sessions of my research assistants. In a pilot study, we screened 2 episodes of a drama serial (Daam) and shared/discussed our analyses. Eighty-nine percent of coders' analyses were 
according to the coding sheet. We discussed and resolved all screening and coding issues of this study. Table\# 2 shows details of codes.

\section{Table: 1}

Details of Pakistani urdu drama serials

\begin{tabular}{|c|c|c|c|c|c|c|}
\hline Drama Serial & Year & IMDb & Writer & Director & $\begin{array}{c}\text { Female Main } \\
\text { Role }\end{array}$ & Plot \\
\hline Daam & 2010 & $8.2 / 10$ & Umera Ahmad & MehreenJabbar & Zara & $\begin{array}{l}\text { A story of Zara's struggle, who } \\
\text { belongs to a lower middle class } \\
\text { family. In spite of many hardships, } \\
\text { she rigorously works hard and } \\
\text { eventually achieves foreign education } \\
\text { and inspiring financial status. }\end{array}$ \\
\hline Hamsafar & 2011 & $9 / 10$ & FarhatIshtiaq & $\begin{array}{c}\text { Sarmad Sultan } \\
\text { Khoosat }\end{array}$ & Kirad & $\begin{array}{l}\text { This drama is about honesty, sacrifice, } \\
\text { loyalty and love of a girl, Khirad. She } \\
\text { belongs to a lower middle class family } \\
\text { and marries under distressed } \\
\text { circumstances with her rich cousin } \\
\text { Ashir. Khirad comes from a very } \\
\text { traditional family. }\end{array}$ \\
\hline $\begin{array}{l}\text { Durr-e- } \\
\text { Shahwar }\end{array}$ & 2012 & $8.5 / 10$ & Umera Ahmad & $\begin{array}{l}\text { Haissam } \\
\text { Hussain }\end{array}$ & Shandana & $\begin{array}{l}\text { The drama shows the trials and } \\
\text { tribulations a woman who has to go } \\
\text { through in order to win the love of her } \\
\text { husband. It has two story lines, of Dur } \\
\text { e Shahwar and her daughter, } \\
\text { Shandana. }\end{array}$ \\
\hline$\overline{Z G H}$ & 2013 & $9 / 10$ & Umera Ahmad & $\begin{array}{l}\text { Sultana } \\
\text { Siddiqui }\end{array}$ & KashafMurtaza & $\begin{array}{l}\text { Story of a self-made girl of a school } \\
\text { teacher whose husband left her and } \\
\text { marries another woman for the sake of } \\
\text { getting a male child. The story focuses } \\
\text { on gender biasness and the difference } \\
\text { between the economic status. }\end{array}$ \\
\hline Digest Writer & 2014 & $8.8 / 10$ & $\begin{array}{l}\text { MadihaShahid, } \\
\text { Umera Ahmad }\end{array}$ & $\begin{array}{l}\text { Ahmad } \\
\text { Kamran }\end{array}$ & Farida & $\begin{array}{l}\text { A young female college student who } \\
\text { belongs to a lower-middle class } \\
\text { family aspires to become a digest } \\
\text { writer. She goes through financial } \\
\text { crisis and social criticism. Finally } \\
\text { achieve recognition and respect. }\end{array}$ \\
\hline Diyar-e-Dil & 2015 & $9.1 / 10$ & FarhatIshtiaq & Haseeb Hassan & $\begin{array}{c}\text { FaarahWali } \\
\text { Khan }\end{array}$ & $\begin{array}{l}\text { Story revolves around on the splinted } \\
\text { family issue with separated parents. } \\
\text { The story concludes a moral lesson } \\
\text { regarding respect, love and care in } \\
\text { relationships. }\end{array}$ \\
\hline Gul-e-Rana & 2016 & $8.1 / 10$ & SamraBukhaki & Farooq Rind & Gul-e-Rana & $\begin{array}{l}\text { Gul-e-Rana, a girl who struggles for } \\
\text { rights, marries to an abusive man } \\
\text { Adeel. She tries to transform Adeel's } \\
\text { mentality. }\end{array}$ \\
\hline $\begin{array}{l}\text { YaqeenKa } \\
\text { Safar }\end{array}$ & 2017 & $8.9 / 10$ & FarhatIshtiaq & $\begin{array}{l}\text { Shehzad } \\
\text { Kashmiri }\end{array}$ & Zubia Khalil & $\begin{array}{l}\text { Story of a struggling young female } \\
\text { doctor, who went through family } \\
\text { crises and sexually exploited by her } \\
\text { boyfriend. }\end{array}$ \\
\hline Khaani & 2018 & $8.2 / 10$ & AsmaNabeel & AnjumShahzad & $\begin{array}{l}\text { Sanam Khan/ } \\
\text { Khaani }\end{array}$ & $\begin{array}{l}\text { A sister struggle to avenge the murder } \\
\text { of her only brother who was killed by } \\
\text { a short-tempered politician's only son. }\end{array}$ \\
\hline EhdeWafa & 2019 & $8.7 / 10$ & Mustafa Afridi & $\begin{array}{l}\text { Muhammad } \\
\text { Saifi Hasan }\end{array}$ & Dua & $\begin{array}{l}\text { Pakistani military TV drama serial } \\
\text { that revolves around stories of four } \\
\text { boys and their girlfriends. Dua is a } \\
\text { girlfriend of a military officer who } \\
\text { struggles for her education and } \\
\text { agency. }\end{array}$ \\
\hline
\end{tabular}


Table: 2

\begin{tabular}{|c|c|c|c|c|c|c|c|c|c|c|}
\hline & $\begin{array}{c}\text { Zara } \\
\text { (Daam, } \\
2010)\end{array}$ & $\begin{array}{c}\text { Khirad } \\
\text { (Hamsafar, } \\
\text { 2011) }\end{array}$ & $\begin{array}{l}\text { Shandana } \\
\text { (Dure } \\
\text { Shahwar, } \\
\text { 2012) }\end{array}$ & $\begin{array}{l}\text { Kashaf } \\
\text { (ZGH } \\
2013)\end{array}$ & $\begin{array}{c}\text { Farida } \\
\text { (Digest } \\
\text { Writer } \\
2014 \text { ) }\end{array}$ & \begin{tabular}{|c|} 
Faarah \\
(Diyar-e- \\
Dil 2015)
\end{tabular} & $\begin{array}{c}\text { Gul-e- } \\
\text { Rana (Gul-e- } \\
\text { Rana2016) }\end{array}$ & $\begin{array}{c}\text { Zubia } \\
\text { Khalil } \\
\text { (YaqeenKa } \\
\text { Safar 2017) }\end{array}$ & $\begin{array}{c}\text { Sanam } \\
\text { Khan } \\
\text { (Khaani } \\
\text { 2018) }\end{array}$ & $\begin{array}{c}\text { Dua } \\
\text { (Ehde } \\
\text { Wafa } \\
\text { 2019) }\end{array}$ \\
\hline Edu & MBBS & MA & MA & MA & Graduate & MBBS & Graduate & MBBS & MA & MBBS. \\
\hline $\begin{array}{l}\text { Job/ } \\
\text { Profession }\end{array}$ & $\begin{array}{c}\text { Doctor } \\
\text { Medical }\end{array}$ & Student & Student & $\begin{array}{c}\text { CSP } \\
\text { officer }\end{array}$ & Writer & \begin{tabular}{|c|} 
Doctor \\
Medical
\end{tabular} & Teacher & $\begin{array}{l}\text { Doctor } \\
\text { Medical }\end{array}$ & $\begin{array}{l}\text { Hospital } \\
\text { Staff } \\
\text { Waiter }\end{array}$ & $\begin{array}{l}\text { Medical } \\
\text { Student }\end{array}$ \\
\hline $\begin{array}{l}\text { Economic } \\
\text { Status }\end{array}$ & $\begin{array}{l}\text { Lower } \\
\text { Middle }\end{array}$ & $\begin{array}{l}\text { Lower } \\
\text { Middle }\end{array}$ & $\begin{array}{l}\text { Middle } \\
\text { Class }\end{array}$ & $\begin{array}{l}\text { Lower } \\
\text { Middle }\end{array}$ & $\begin{array}{l}\text { Lower } \\
\text { Middle }\end{array}$ & $\begin{array}{l}\text { Middle } \\
\text { Class }\end{array}$ & $\begin{array}{l}\text { Lower } \\
\text { Middle }\end{array}$ & $\begin{array}{l}\text { Middle } \\
\text { Class }\end{array}$ & $\begin{array}{c}\text { Middle } \\
\text { Class }\end{array}$ & $\begin{array}{c}\text { Middle } \\
\text { Class }\end{array}$ \\
\hline $\begin{array}{l}\text { Culinary } \\
\text { Skills }\end{array}$ & Yes & Yes & Yes & Yes & Yes & Yes & Yes & Yes & Yes & Yes \\
\hline $\begin{array}{l}\text { House- } \\
\text { keeping }\end{array}$ & Yes & Yes & Yes & Yes & Yes & Yes & Yes & Yes & Yes & Yes \\
\hline $\begin{array}{l}\text { Childcare/F } \\
\text { amily Care }\end{array}$ & Yes & Yes & Yes & Yes & Yes & Yes & Yes & Yes & Yes & Yes \\
\hline $\begin{array}{l}\text { Traditional } \\
\text { dress }\end{array}$ & Yes & Yes & Yes & Yes & Yes & Yes & Yes & Yes & Yes & Yes \\
\hline Progressive & Yes & Yes & Yes & Yes & Yes & Yes & Yes & Yes & Yes & Yes \\
\hline $\begin{array}{l}\text { Women } \\
\text { Agency }\end{array}$ & \begin{tabular}{|c} 
In \\
beginning \\
No, At \\
the end \\
Yes
\end{tabular} & $\begin{array}{c}\text { In } \\
\text { beginning } \\
\text { No, At the } \\
\text { end Yes }\end{array}$ & Yes & \begin{tabular}{|c|} 
In \\
beginning \\
No, At the \\
end Yes
\end{tabular} & \begin{tabular}{|c|} 
In \\
beginning \\
No, At the \\
end Yes
\end{tabular} & $\begin{array}{c}\text { In } \\
\text { beginning } \\
\text { No, At } \\
\text { the end } \\
\text { Yes }\end{array}$ & $\begin{array}{l}\text { In beginning } \\
\text { No, At the } \\
\text { end Yes }\end{array}$ & $\begin{array}{c}\text { In } \\
\text { beginning } \\
\text { No, At the } \\
\text { end Yes }\end{array}$ & Yes & Yes \\
\hline
\end{tabular}

\section{Results and Discussion}

The colors of common characteristics of these protagonists help us to create a big picture of new Pakistani woman. The vital element in the under study female characters of the corpus, is their 'progressive' attitude. These female characters always put efforts to improve their existing economic status. That is why, their willingness to update their knowledge and familiarize themselves with science and new technology is highly visible in the stories of dramas under study. With the development of storyline, enhancement in the social status of these female characters is another proof of their attitude towards progress. Dramatists consider education as a pathway to success and progress. All these protagonists in the corpus are depicted formally educated but the level of their social class and education varieties slightly in every drama. Out of ten, four characters (Zara, Faarah, Dua \& Zubia) complete their degrees in medicine and the rest of six characters (Khirad, Shandana, Kashaf, Farida, Gul \& Sanam) get Bachelors and Masters degrees in different fields (see table \# 2). These characters are shown incredibly committed in achieve their goals. 
The situation of female representation in the contemporary Pakistani Urdu dramas is completely changed from the past. These dramas break the mold of past archetypal, meek, and passive women and present a comparatively liberal, broadminded, and independent model. Dutoya (2018b) defines "new woman" as an educated, professional, urban woman who takes care of her home and family and acts as a respectable Muslim woman. Female protagonists of contemporary Pakistani television dramas are the embodiment of this definition. They are strong charactered progressive girls who have a solid bonding with their culture and tradition. These powerful girls have courage to raise their voices for their rights. These female protagonists appear on screen in low notes but gradually with their courteous attitude and constant struggle get dominating position in dramas. For example, in drama serial Yaqeen Ka Safar (2017), Zubia's father is showcased in the role of controlling and egoistic male but eventually after observing Zubia's attitude and progress, he feels sorry for his wrong guess and chauvinistic behavior. The female protagonist Zubia empowers herself with professional education and begins her own successful life. Similarly, all other heroines of the corpus reflect respect towards religious ethics and familial values.

There is a correlation between traditional and religious bonding and economic status of the families presented in these dramas. In drama serial Digest Writer Farida belongs to a lower middle class traditional family. Her father always covers his head with a round white cap, which is usually used during prayers as a head covering (Digest Writer Episode \#07 HUM TV Drama, n.d.). Heroines of five dramas form the corpus, belong to lower middle class families. Their outfits, etiquettes, dialogues and backdrops also showcase traditional and religious house environment. While the rest of the heroines belong to middle class, their families are presented less religious but traditional and trendy.

The appearance of Pakistani 'New woman' is simple and graceful. In this study, I found many commonalities in the appearance and attire of drama-heroines. They always appear with comfortable, simple, traditional and sometimes trendy outfits with light make-up and well-done hair. Throughout dramas, these female characters are the focal point of entire story. These dramas highlight their talent and capabilities rather than their outfits. In Zindagi Gulzar Hai (ZGH), Kashaf, who belongs to a poor family focuses on her studies and self-empowerment. She always wears simple traditional clothes with a headcovering (Zindagi Gulzar Hai | Episode \# $06 \mid$ Fawad Khan | Sanam Saeed | HD, n.d.). Similarly, other female protagonists (Zara, Shandana, Farida, Faarah, Zubia, Sanam, Gul, Khirad \& Dua) also appear in the same manner. The idea is that nothing can divert the attention of these 'new-women' from their objectives. Their main focus is selfempowerment. Once they achieve their targets, they enjoy their success with their whole family. During this journey, they may move slightly beyond the boundaries of their tradition, but they remain supporters of their national culture. 
Education and knowledge is the pivotal point of empowerment and agency. These characters struggle to achieve their specific goals through education. In addition to the higher educational achievements and having professionally sound carrier the new-women are equally capable in household skills (see table \#2). Cooking, sewing, housekeeping and childcare are the responsibilities that do not bother them. They do not consider these activities as an obstacle in their progress, rather most of them do it by choice (Humsafar | Episode \#17 | Mahira Khan | Fawad Khan | SuperHit Serial | Hum TV, n.d.).

The normative model of new-woman is not oppressed and weak. She has courage to stand against social injustice and inequalities. Female protagonists, who are showcased as normative models of new-womanhood, are simple and modest. Instead of glamour, they emphasize personality building and self-grooming. Overall, the lifestyle of these heroines depicts a humble, progressive, and self-made approach. They stay respectful towards elders and wait for the right time to see the change.

New-woman realizes that courtesy is the key of love and success. These dramas showcase their heroines courteous towards their husbands. While addressing them they use the Urdu word aap (you) which is a polite way to address someone important (Durr e Shahwar epi. \#1 n.d.). Similarly, asking permission before going out and asking husband's opinion before making any important decision is a way to give importance to your life-partner (Humsafar | Episode \#19| Mahira Khan | Fawad Khan | SuperHit Serial $\mid$ Hum TV, n.d.).

The achievements of these female protagonists, motivate their families and friends to support them in their way to success. Zara gets first position in a debating contest (Daam Episode 3 (Pakistani Drama), n.d.). She spends the amount of her cash prize in paying off her family's grocery bills. After becoming a doctor, she supports her family financially. Farida (Digest Writer Episode \#07 HUM TV Drama, n.d.) also belongs to a lower middle class family. Her family encounters multiple constraints e.g., poverty, social pressure of women marriages at a specific age, people's views against women education, and patriarchal pressure against women's income. However, Farida proves herself in studies and uses her talent of story writing as a profession. She gets recognition and respect in the field of storytelling and also financially supports her family. In this case, intersectionality of oppressions also provides a ray of hope for new-women who have the moral courage to overcome these constraints and prove themselves as a savior. Drama serials Zindagi Gulzar Hai, Daam, Hamsafar, and Ehd-e-Wafa are a few examples where heroines are showcased as champion and rescuer of their respective families.

'New-woman' stands up against the economic discriminations of the society. Her 
progressive approach helps her in her self-empowerment. Her determination and selfcommitment ameliorates the adverse effects of poverty. Like the other progressive and modest Indian women as mentioned by Talukdar and Linders (2013), these Pakistani middle-class 'new-women cannot be defined solely through material signs. Their line of action and struggle for their professional growth is a great inspirational source for others.

Pakistani Urdu dramas address issues of economic inequalities by portraying characters of diverse economic status (see the portion of social status in table \# 2,). In drama serial Daam (2010), Zara belongs to a lower middle class family. Her elder sister is the only breadwinner as her father is jobless person; thus, she has to support her family. The acceptance of women in any role other than housekeeper is unusual for a patriarchal society. The writers have constructed these strong female roles to create balance between Pakistani familial traditions and modernity. The enlightenment and modernity of these characters are based on love for humanity and true social relations. In drama serial Daam (2010), the heroine who is a doctor by profession sacrifices her love to buy happiness for her sister and improve the financial status of her whole family.

\section{Conclusions and Recommendations}

The base of heterogeneous portrayal of 'new womanhood' in Pakistani Urdu TV dramas is a good moral character and women self-empowerment. Although new-woman exercises her agency, the element of tolerance and patience can also be observed while resisting excessive male dominance and discrimination. A strong bonding with Pakistani culture is also imperative for female protagonists of the corpus. As 'new-women' belong to a middle class economic status, they are also the custodian of good traditional values. They are broadminded and liberal on one hand, but on the other hand they do not compromise on motherhood and wifely duties. These female characters do not lose their identity and love for indigenous culture, literature, and social norms. These women in dramas are not overly conservative and rigid in their behavior; they do not blindly follow the obsolete regional customs that create hindrance in self-empowerment and underpin economic dependency. They achieve agency not only by being remunerative but also by winning hearts of their family members with love and respect. New-woman is neither a puritan nor is she a representative of western culture. She is rather a blend of East and West - a beautiful picture of modesty and modernity that does not have any clashes with patriotism and religion.

\section{References}


Abbas, S. (2018). Conventional Female Images, Islamization and its Outcomes: A study of Pakistani TV Dramas. Online Journal of Communication and Media Technologies, vol.8:2, pp.20-38.

Anand, T. (2014). The Game Changer: A Brief History of Television in Pakistan. Ushba Publishing International

Carilli, T. \& Campbell, J. (2013). Challenging Images of Women in the Media: Reinventing Women's Lives. Lexington Books, Lanham, Md.

Chatterjee, P. (1989). Colonialism, Nationalism, and Colonialized Women: The Contest in India. American Ethnologist, vol.16:4, pp.622-633.

Cheema, M. (2018). Women and TV Culture in Pakistan: Gender, Islam and National Identity. London: I.B. Tauris.

Daam Episode 3 (Pakistani drama). (2010). Retrieved January 30, 2020, from https://www.youtube.com/watch?v=51ReeTmpUgI\&t=3s

Dawkins, S. \& Wynd, I. (2009). Video Production: Putting Theory into Practice. Macmillan International Higher Education.

Deputy Nazeer Ahmed. (n.d.). Mirat Ul Uroos by Deputy Nazeer Ahmad. Retrieved on $\begin{array}{llll}\text { January } & \text { 30, 2020, from }\end{array}$ http://archive.org/details/MiratUlUroosByDeputyNazeerAhmad

Devji, F. F. (1991). Gender and the Politics of Space: The Movement for Women's Reform in Muslim India, 1857-1900. South Asia: Journal of South Asian Studies, vol.14:1, pp.141-153.

Digest Writer Episode \#07 HUM TV Drama. (n.d.). Retrieved January 30, 2020, from https://www.youtube.com/watch?v=vHb-Ni0X71o

Dur e shahwar epi 1. (n.d.). Retrieved January 30, 2020, from https://www.youtube.com/ watch?v=t14IexBTQMU

Dutoya, V. (2018a). The New Heroine? Gender Representations in Contemporary Pakistani Dramas. In N. Hussein (Ed.), Rethinking New Womanhood (pp. 71-93). Springer International Publishing. https://doi.org/10.1007/978-3-319-67900-6_4

Dutoya, V. (2018b). The New Heroine? Gender Representations in Contemporary Pakistani Dramas. In N. Hussein (Ed.), Rethinking New Womanhood: Practices of 
Gender, Class, Culture and Religion in South Asia (pp. 71-93). Springer International Publishing. https://doi.org/10.1007/978-3-319-67900-6_4

Editorial. DAWN (2020, April 26). Blaming women. DAWN.COM. https://www.dawn.com/news/1552294

Editorial. (1996, March 11). The Pakistan Times, 27.

Ehd-e-Wafa | Episode \#2 | Hum TV. (2012). Retrieved January 30, 2020, from https://www.youtube.com/watch?v=Oo-LW5HfH7w

Frith, K. T. \& Karan, K. (2008). Commercializing Women: Images of Asian Women in the Media. Hampton Press.

Hasan, B. (2000). Uncensored: An Eyewitness Account of Abuse of Power and Media in Pakistan. Royal Book Company, Karachi, Pakistan.

Hiten Tejwani keen to work in a Pakistani TV drama. (2014, September 17). Hindustan Times (New Delhi, India). https://search.proquest.com/docview/1562513808

Humsafar | Episode \#17 | Mahira Khan | Fawad Khan | SuperHit Serial | Hum TV. (2012). Retrieved January 30, 2020, from https://www.youtube.com/watch?v=HlEJkZSbBio

Humsafar | Episode \#19 | Mahira Khan | Fawad Khan | SuperHit Serial | Hum TV. (2012). Retrieved January 30, 2020, from https://www.youtube.com/watch?v=BfaI7Agg2_4

Hussein, N. (2018a). Bangladeshi New Women's 'Smart' Dressing: Negotiating Class, Culture, and Religion. In N. Hussein (Ed.), Rethinking New Womanhood: Practices of Gender, Class, Culture and Religion in South Asia (pp. 97-121). Cham : Palgrave Macmillan.

Hussein, N. (2018b). Rethinking New Womanhood: Practices of Gender, Class, Culture and Religion in South Asia. Cham : Palgrave Macmillan.

Iqbal, H. (2012). Gender Discrimination: Implications for Pakistan Security. IOSR Journal of Humanities and Social Science, vol.1:4, pp.16-25.

Jamal, A. (2013). Jamaat-e-Islami Women in Pakistan: Vanguard of a New Modernity? Syracuse University Press. 
Kilbourne, J. (1999). Deadly Persuasion: Why Women and Girls Must Fight the Addictive Power of Advertising. The Free Press.

Kopf, D. I. (1995). Review of the Nation and Its Fragments: Colonial and Postcolonial Histories [Review of Review of The Nation and Its Fragments: Colonial and Postcolonial Histories, by P. Chatterjee]. The American Historical Review, vol.100:4, pp.1281-1282.

Kothari, S. (2005). From Genre to Zanaana: Urdu Television Drama Serials and Women's Culture in Pakistan. Contemporary South Asia, vol.14:3, pp.289-305.

Moolji, S. K.-. (2018). Akbari and Asghari Reappear. In Forging the Ideal Educated Girl: The Production of Desirable Subjects in Muslim South Asia. University of California Press. http://www.jstor.com/stable/10.1525/j.ctv233kth.9

Mumtaz, K. \& Shaheed, F. (1987). Women of Pakistan: Two Steps Forward, One Step Back? Zed Books, London.

Pal, I.-D. (1990). Women and Islam in Pakistan. Middle Eastern Studies, vol.26:4, pp.449-464.

Parvez, N. (1998). Pakistan Television Drama and Social Change: A Research Paradigm. Department of Mass Communication, University of Karachi, Karachi, Pakistan.

Reimer, V. \& Ahmed, R. (2012). Feeling Good Never Looked Better. In Challenging Images of Women in the Media Reinventing Women's Lives (pp. 13-27). Lexington Books, Lanham, Md.

Saudi Arabia Interested to Show Pakistani TV Dramas on Saudi Channels. (2018, September 21). The Balochistan Times. https://search.proquest.com/docview/2111043712

Shah, H. A. (2018, September 6). How Patriarchy Holds an Unequal Order Together. The Friday Times, $X X X(31)$. https://www.thefridaytimes.com/how-patriarchy-holdsan-unequal-order-together/

Shah, S. M. H., \& Panhwar, S. H. (2014). Bhutto, Zia and Islam, Shaheed Bhutto Publications, Larkana. 
Silva, N. (2003). Shameless Women: Repression and Resistance in We Sinful Women: Contemporary Urdu Feminist Poetry. Meridians, vol.3:2, pp.28-51.

Talib, S. \& Idrees, Z. (2012). Pakistani Media and Disempowerment of Women. In Challenging Images of Women in the Media Reinventing Women's Lives (pp. 3948). Lexington Books, Lanham, Md.

Talukdar, J. \& Linders, A. (2013). Gender, Class Aspirations, and Emerging Fields of Body Work in Urban India. Qualitative Sociology, vol.36:1, pp.101-123.

Thanvi. A.A. (2000). Bahishti Zewar (Eng.) *. Adam Publishers \& Distributors.

Walsh, J. \& Chatterjee, I. (2001). Gender, Slavery and Law in Colonial India. The American Historical Review, vol.106:1, p.152.

Weiss, A. M. (1990). Benazir Bhutto and the Future of Women in Pakistan. Asian Survey, vol.30:5, pp.433-445.

Zindagi Gulzar Hai $\mid$ Episode \# $06 \mid$ Fawad Khan | Sanam Saeed | HD. (2013). Retrieved January 30, 2020, from https://www.youtube.com/watch?v=S22wWKJoR2c

Dr. Saleem Abbas is an Assistant Professor in the Department of Mass Communication, Forman Christian College University, Lahore, Pakistan.

Dr. Firasat Jabeen is an Assistant Professor in the Department of Mass Communication, Forman Christian College University, Lahore, Pakistan.

Muhammad Askari is Ph.D Scholar in the Department of Mass Communication, University of Karachi, Karachi, Pakistan. 